\title{
Global public-private partnerships and the new constitutionalism of the refugee regime
}

\author{
M A R K M A C H A C E K \\ Simon Fraser University AQ6069 - 8888 University Drive, Burnaby, British Columbia, Canada V5A 1S6
}

Email: mmachace@sfu.ca

\begin{abstract}
Since the early 2000s, regimes and institutions of global governance have undergone a paradigmatic shift in their relations with multinational corporations. The United Nations, in particular, has increasingly embraced big business as 'partner' in humanitarian response and development with the establishment of 'global publicprivate partnerships' (GP3s). This article situates this emerging mode of global governance within the recent academic discussions on Global Constitutionalism from a critical political economy perspective, focusing on the case of the UN Refugee Agency's GP3s in refugee protection and assistance. Critically inquiring into GP3s not only as informal global constitutional arrangements but also as a set of political relations, this article asks: what is the constitutional and political nature of UNHCRbusiness partnerships? What impacts, if any, do they have on the agency? And, what does this mean for understanding global constitutionalism? The article argues that UNHCR partnerships are constituted as asymmetrical political relations in terms of their distributions of power, benefits, risks and commitments, that they are having neoliberal-oriented constitutive effects on the agency and that these constitutional dynamics challenge the more mainstream and liberal-based conceptualisations, analyses and promotion of current global constitutionalism processes.
\end{abstract}

Keywords: critical political economy; global constitutionalism; global public-private partnerships; new constitutionalism; UNHCR

\section{Introduction}

Since the early 2000s, regimes and institutions of global governance have undergone a paradigmatic shift in their relations with multinational corporations. The United Nations, in particular, has increasingly embraced big business as 'partner' in humanitarian response and development with the establishment of global public-private partnerships (GP3s). In the fields of International Relations and Global Public Policy, GP3s are generally understood as constituting-either formally or informally-institutionalised, long-term and multidimensional engagements between public and for-profit 
entities whose activities involve the provision of global public goods (Bull and McNeill 2007; Bexell and Morth 2010). As this study will substantiate, GP3s are especially novel due to their roles in global agenda-setting and decision-making processes (Schäferhoff et al. 2009: 453; Gregoratti 2010).

This article situates GP3s within the recent academic discussions on Global Constitutionalism (GlobCon). GlobCon is understood to be processes facilitating semblances of constitution-like features at the global level through international agreements, organisations and regimes that establish quasi-permanent formal and/or informal laws, rules, norms and delegations of authority. Naturally, parallel academic debates have emerged on the politics of GlobCon, more generally, and its particular manifestations, including GP3s. While some argue that these processes increase the potential for international order, collaboration and democracy (Ruggie 2004; Peters 2009), others hold that they reflect relations of power and/or the interests of global capital (Brown 2012; Gregoratti 2012). Aside from Gregoratti's (2010) study of the UN Development Programme's (UNDP) partnerships, current research is lacking empirical and critical political economy analyses of GP3s as a set of power relations and has largely neglected consideration of the potential impacts these arrangements may be having on the international institutions and regimes that engage in them. Furthermore, we are still uninformed of the insights these particular governance arrangements may provide for the substance and theory of GlobCon - a theoretical focus that has too often overlooked multinational corporations as central actors in constitutionalism processes. This article, therefore, employs a critical research agenda inquiring into the political economy of GP3s, their effects on public global institutions and their ramifications for theorising GlobCon and global governance. Focusing on the GP3s of the United Nations High Commissioner for Refugees (UNHCR) - purportedly geared towards the protection and assistance of the world's refugee communities - this article asks a) what is the constitutional and political nature of UNHCR-business partnerships? b) what impacts, if any, do they have on the agency? and c) what does this mean for understanding Global Constitutionalism?

Following a review of the GlobCon and GP3 literatures, this article dissects UNHCR-business partnerships from a critical political economy perspective that emphasises power, the structure of the global political economy, ideology and social forces. It argues that a) UNHCR GP3s are constituted as asymmetrical political relations in terms of their power distributions and the benefits, risks and commitments each actor accrues, b) that they are having constitutive effects on the agency in a manner synonymous with Stephen Gill's $(1998 ; 2014)$ conception of 'new constitutionalism' - an existential neoliberal reconfiguration that reconstitutionalises and embeds the agency within the forces of the capitalist 
global political economy, thereby further constitutionalising the structural power of capital - and c) that these political and constitutive dynamics of GP3s challenge the more mainstream and liberal-based conceptualisations, analyses and promotion of current GlobCon processes.

\section{Global constitutionalism and global public-private partnerships}

\section{The many 'constitutionalisms'}

Global Constitutionalism (GlobCon) is a multidisciplinary academic focus that seeks to understand and explain the legal, institutional and normative mechanisms that are understood to be facilitating qualities akin to national constitutions at the global level. In the disciplines of International Relations (IR) and Global Political Economy (GPE), this research agenda is one of the latest approaches in a long line of academic attention to international cooperation and compliance. Since the 1970s, (neo)liberal institutionalist scholars, working from the basic assumptions of the realist paradigm, have theorised the effects of international organisations, law and 'complex interdependence' on global stability and international cooperation (Keohane and Nye 1977). Regime analysis continued this agenda in the 1980s, further emphasising the impact of principles, norms, rules and decision-making procedures in particular global issue areas (Krasner 1983; Kratochwil and Ruggie 1986). The attention to institutional and normative constraints on state behaviour birthed a prominence of rationalist-based approaches, reinvigorating the employment of formal game theory and stimulating efforts toward conceptualising the informal, 'soft' dimensions of collective action (see Stein 1982; Snidal 1985; Lipson 1991). In conjunction with the end of the Cold War, the increasing prominence of international institutions and legal regimes and the intensification of globalisation, the 1990s gave rise to the concept of 'global governance', more generally conceived, which expanded the ontological purview of the succeeding approaches to include a more prominent role for non-state actors, the global economy and globalisation processes (Weiss 2000). These successive approaches have all shared a set of challenges by more power-oriented paradigms and critical theories which have problematised their liberal normative dimensions and politically neutral conceptions of regimes, institutions and international laws (Gill and Cutler 2014).

The more recent academic focus on GlobCon advances many of the same questions as the predominately liberal IR tradition but refocuses the discussion around international law and legal theory. The concept of GlobCon is generally understood to be various processes resembling constitutions or constitution-like features at the global level through 
international agreements, institutions and regimes that establish quasipermanent formal and/or informal laws, rules, norms and delegations of authority (Peters 2009; Wiener et al. 2012). GlobCon approaches of all stripes tend to conceptualise constitutions more broadly to include not only hard, codified laws and constitutions - such as those constituting the European Union or the World Trade Organization - but also the soft and informal rules, norms and processes that constitute many international legal frameworks and regimes of global governance (see McCorquodale 2013; Tully et al. 2016: 2). Some GlobCon authors have showcased the centrality of informality in particular GlobCon processes. McCorquodale (2013), for example, outlines the soft, norm-oriented constitution of global social responsibility frameworks. Certain corporate codes of conduct in the human rights regime, he shows, defy formal institutionalisation and instead are constituted by voluntarily agreed upon behavioural norms. This article's study further illustrates this GlobCon dynamic in the GP3 process.

The discipline of (International) Legal Studies has given birth to a variety of approaches, both in and outside of the liberal tradition, that have conceptualised a multitude of GlobCon processes. Scholars employing the basic assumptions of liberal IR theory, including the ideas of functionalism and political pluralism of legal frameworks (see Buzan 1996: 55), are optimistic of, and often promote, GlobCon processes to 'improve the effectiveness and fairness of the international legal order' (Peters 2009: 397). It is believed that the rule of law will constitute and limit the exercise of political authority globally, establish a more level international playing field and facilitate collective action (ibid). Some theorists of the Global Administrative Law perspective on GlobCon, for instance, offer insights into a growing 'global administrative space' outside of the purview of formal international legal bodies that nonetheless facilitates processes of global regulation and administration (Kingsbury et al. 2005). This space is constituted largely by Western-based initiatives reflecting the administrative liberal state and is at least partially justified by cosmopolitan conceptions of individual rights, economic rights and democracy (ibid: 51). This view closely corresponds with a wider body of GlobCon literature that is committed to the liberal universal principles of human rights, democracy and the rule of law - the 'Trinitarian mantra of the constitutionalist faith' (Kumm et al. 2014; Dunoff et al. 2015: 1).

A number of alternative approaches outside of the liberal tradition have developed in the focus on GlobCon and related processes. Teubner and Norbury's (2012) Systems Theory, for example, deconstructs the cosmopolitan idea of a truly 'global' constitutionalism, preferring instead to focus on the fragmentation of global law according to relatively autonomous, issue-specific 
legal systems and social sub-systems. He advocates for a 'societal constitutionalism' that recognises civil constitutions of such sub-systems in global society that are outside the mandate of formal political and legal institutions. Other GlobCon scholars have taken a more radical ontological departure from traditional international legal theory with their application of Habermasian Communicative Theory. This approach posits a universalism 'beyond the Kantian paradigm of universalistic individualism' based on notions of intersubjectivities and communication (Bogdandy and Dellavalle 2009: 5-6). In this view, GlobCon is understood to be (potentially) deliberative or communicative processes that, despite the plurality of cultures and rationalities at the global level, are bound by a universal communicative rationality (ibid). This universal rationality has the potential to facilitate understandings and norms on a global scale.

In the same vein as its theoretical predecessors in IR theory, GlobCon has spawned several critical approaches that problematise the field's predominating normative commitments and optimism of GlobCon processes. These approaches take more seriously the question of power in the 'rule of law' by de-neutralising legal frameworks and re-orienting inquiry to focus on 'rule through law' (Rajkovic 2010). One stream of critical approaches, the Postmodern perspective, employs Foucauldian notions such as the knowledge/power dynamic, positing constitutionalism as a terrain of discursive contests (Lawrence 2013). Rajkovic (2010) extends Foucault's concept of governmentality to global legal orders, treating global legal and constitutional processes as a rationality of government and technique of power.

Critical political economy perspectives provide a further stream of critical thought in GlobCon. These approaches embed a historical analysis of GlobCon processes within their global political economy context. Postcolonial dependency theorists outline the history of international law as a mechanism of power and legitimisation of existing unequal global coreperiphery relations (Kennedy 2013). International law has been shown to constitute a 'dynamic of difference' between the Western 'civilised world' and the 'primitive' other, thereby legitimising (post)colonial interventions (Anghie 2008).

Throughout these many global constitutionalisms, non-state actors and those not a part of formal international institutions are considered in GlobCon processes. Global Administrative Law theorists have discussed global spaces composed of states, individuals, firms and non-governmental organisations (NGOs) (Kingsbury et al. 2005), Systems theorists have considered the constitutionalisation of social functions via multinational corporations and transnational groups (Teubner and Norbury 2012) and critical political economy theorists have placed market actors and processes 
at the centre of GlobCon analysis (Anghie 2008). Critical neo-Gramscian theory, in particular, magnifies this focus by emphasising social forces and their particular manifestations (i.e. corporations and civil society). This approach has advanced GlobCon as a site of both hegemony and counterhegemony, dominance or emancipation amongst competing social forces (Buckel and Fischer-Lescano 2009).

Neo-Gramscian theory provides a valuable complement to other critical political economy approaches with its extension of the concept of power to include both its structural and ideological underpinnings (Brown 2012; Gill and Cutler 2014). Like Postmodern and Dependency theorists, neoGramscians are epistemologically and normatively critical; sceptics of supposed academic neutrality and oriented towards the explicit goal of social and political emancipation. From this vantage point, the predominating traditional and liberal GlobCon approaches offer mere 'problem-solving theories' that accept the general global order of inequality by offering piecemeal changes to help order, stabilise and reify such a system (Cox 1981). Neo-Gramscian theory, on the other hand, de-naturalises and deneutralises the system in attempts to change it, inquiring into the cui bono? of all political and economic relations, asking, in this case, 'constitutionalism for what and for whom?' (Brown 2012; Gill and Cutler 2014). Like other critical approaches, neo-Gramscian theory's point of analytical departure consists of the assumption that, in contrast with the functionalism and pluralism of more traditional approaches, power pervades constitutions and legal orders which are themselves manifestations of global political economy relations.

First conceptualised by Stephen Gill (1995), the critical New Constitutionalist approach is encompassed within the neo-Gramscian theoretical lineage in IR/GPE. Rather than viewing the state as the ontological starting point in international relations, neo-Gramscian theory and New Constitutionalist focuses on social forces - such as capital and multinational corporations or labour and counter social movements - as the primary unit and level of analyses, resulting in a more 'global' (vs. 'international') analysis. It is essentially a historical materialist theory that views power as constituted by the relations of capitalist production yet moves beyond the constraining economism of traditional Marxism with an emphasis on ideology (or ideas more generally) and its co-constituting relationship with material power. Power, then, is viewed as a complex of instrumental-structural-discursive capacities that are constituted by both structural and agential forces (Cox 1981; 1987; Morton 2003; Farrands and Worth 2005). The complex between productive capacities and ideological legitimacy and authority what constitutes the structure of the global political economy - is at the centre of this approach to explaining global relations of dominance and/or 
hegemony and to theorising potential avenues of political contestation and change. Buckel and Fischer-Lescano (2009), for example, extend the neoGramscian notion of hegemony - or, dominance by consent - to global law. They find that global constitutionalism provides a site and process of both hegemony and counter-hegemonic movements led by civil society actors (i.e. the environmentalism and human rights movements).

With a closer eye to GlobCon processes than neo-Gramcian theorists more generally, New Constitutionalists view the processes of GlobCon as a mechanism for the constitutionalisation and consolidation of global neoliberalism ${ }^{1}$ in the interests of capitalist social forces. Gill and Cutler (2014) have demonstrated such new constitutionalist processes occurring at the state and interstate level - such as bilateral investment treaties or World Trade Organization rules - to be locking states into the neoliberal global economy, essentially undermining state autonomy and national democratic processes. Rather than contextualising constitutionalism as apolitical or neutral pluralist legal processes, global constitutions - broadly defined as a resultant of both de facto and de jure norms, rules and policies - are situated in, and constituted by, structural power and legitimised through ideology and discourse. They function at the level of both states and global institutions to politically, juridically and ideologically restructure governance forms and institutionalise policies and discourses conducive to neoliberal development. The new constitutionalism essentially reconstitutes public institutions as free-market facilitators, locking-in market- and corporate-friendly policies (Gill, 1995; 1998; 2002; Cutler 2014).

\section{Constitutionalising global public-private partnerships and IR/GPE}

Subsequent to the end of the Cold War and intensifying globalisation processes, scholars in IR/GPE have increasingly turned attention to corporate actors and market processes in global governance (Cutler et al. 1999; Higgot et al. 2000; Hall and Biersteker 2002; Ruggie 2004). Multinational corporations have been shown, for example, to have impacted global trade rules (Cutler 2010), intellectual property rights (Sell 2000), global environmental regulatory schemes (Chatterjee and Finger 1994; Levy and Egan 2000) and to have formed a number of private international regimes of industry-specific self-regulation (Cutler et al. 1999; Haufler 2000),

1 Neoliberalism, in this sense, refers to a dominating global economic ideology based on principles of free markets, the minimisation of public regulation and profit-driven development (Gill and Cutler 2014). Soederberg $(2007 ; 2012)$ has demonstrated the dominance of these principles at the global level, showing their influence in, for example, UN development policy and the post-2008 global crisis G20 Summits. 
thereby playing a large part in constituting new modes of global governance. Beginning in the early 2000s, considerable scholarly attention has been given to market processes in the multilateral system, including UN-business relations and the evolving GP3 process (see Schäferhoff et al. 2009; Andonova 2010; Bull and McNeill 2010).

GP3s are generally understood as formally or informally institutionalised, long-term and multidimensional engagements between public and forprofit entities whose activities involve the provision of global public goods (ibid; Bexell and Morth 2010). Specifically, those a part of GP3s are multilateral or international institutions and large multinational corporations or corporate foundations and their activities are geared towards the particular mandate of those public institutions. GP3s are 'newer' forms of public-private engagements that include both the increasing and intensification of private sector involvement in all stages of the global policy process, most notably at the agenda-setting and decision-making phases (ibid). These partnerships have manifested in a variety of forms and capacities - as information and technology sharing between the UN Educational, Scientific and Cultural Organization (UNESCO) and Microsoft (Bull 2010), co-management of development initiatives between the UNDP and Rio Tinto (Gregoratti 2010) and, as this article illustrates, as regularised ideational (i.e. knowledge-sharing, consultancy, advocacy) engagements between the UNHCR and business partners toward the provision of refugee protection and assistance.

The ongoing constitutionalisation of GP3s can be described as a paradigmatic about-face by the UN as these arrangements evolved out of a historically antagonistic relationship between the institution and the business sector. During the Cold War, UN politics were largely shaped by an institutionalised North-South divide with the formation of the Group of 77 (G77) and the subsequent UN Conference on Trade and Development which sought a series of interventionist policies on global corporate conduct. Discourses of a New International Economic Order began to emerge and the G77 sought to establish an international code of conduct - a legally binding constitutionalisation of corporate behaviour - through the creation of the UN Commission on Transnational Corporations (UNCTC) (Therien and Pouliot 2006). Tensions between the UN and business eased in the 1990s (ibid) as the end of the Cold War centred power in the West and heralded in an increasingly globalised and liberalised political economy (Gill 1998). While intensifying globalisation processes were changing the global landscape, the number, activities and legal rights of corporations expanded exponentially (Wilks 2013). Simultaneously, the UN was encountering serious contestations to its legitimacy, particularly in the West where it faced intense criticisms of interventionism, ineffectiveness 
and irrelevance (Andonova 2010). As Bull and McNeill (2007: 7) posit, the proceeding abolition of the UNCTC in 1995 is often viewed as a power shift toward the private sector vis-à-vis the multilateral system within this historical context.

The constitutionalisation of UN GP3s began in 1997 as Kofi Annan, himself a graduate of Massachusetts Institute of Technology business school, assumed the position of UN Secretary-General. Facing legitimacy and financial crises - largely as a result of unpaid membership arrears on the part of the US - and a global backlash against global neoliberalism, Annan committed himself to reforming and opening up the UN, declaring a 'new universal understanding that market forces are essential for development' to the World Economic Forum, thereby injecting the idea of 'partnerships' with the corporate sector in the UN discourse (UN 1999; Tesner and Kell 2000: 32). In a series of meetings with the International Chamber of Commerce (ICC), Annan affirmed his commitment to GP3s, proposing the Global Compact of Shared Values and Principles - the most comprehensive and well-known global partnership programme. Emphasising the declining legitimacy of global neoliberalism mounted by the antiglobalisation movement, Annan offered the idea of the Global Compact to 'give a face to the global market' (UN 1999) through facilitating global corporate social responsibility (CSR) initiatives outlined in its defining principles (Kell and Ruggie 1999). In 2000, just months after the unprecedented anti-globalisation protests at the WTO meeting in Seattle, the Global Compact was launched.

The Global Compact, representing the UN's GP3 approach in general, was constituted in a manner that reflected the increasing prominence of multinational corporations in global governance and the informal and dynamic nature of global constitutionalism. According to its architects and proponents, UN-corporate partnerships constitute an emerging form of 'network governance' conducted under an informal and de facto set of rules, norms and delegations of authority (Kell and Ruggie 1999; Ruggie 2001). Neglecting any legally binding responsibilities and enforcement mechanisms, the Global Compact operates through soft social mechanisms that are believed to induce social learning and the diffusion of UN values to instigate CSR initiatives. This design is in stark contrast to the hard, codified regulations initially sought by the UN and more closely corresponds with the approach supported by the ICC and other free market advocates (Fritsch 2008: 11-12).

Proposed as 'mutually beneficial' arrangements (Tesner and Kell 2000), GP3s are designed to leverage both the material resources and the knowledge and expertise of the corporate sector while contributing to corporate image and market development via their involvement in global public goods 
provisions (Kell and Ruggie 1999; Bexell and Morth 2010). Increasingly, as this article's case will show, GP3s constitute the intensification of corporate knowledge-sharing, consultancy and advocacy activities and forums that play a role in the UN's agenda-setting and decision-making processes. This delegation of authority to corporate actors has been legitimised according to the economic rational of private sector efficiencies, public sector inefficiencies, shared public-private interests in public goods and the liberal notions of participatory and democratic global governance (Reinicke 2000; Reinicke and Deng 2000; Ruggie, 2001; 2004; Rasche and Waddock 2014). GP3s have been posited by their advocates as the latest liberal compromise that addresses the societal backlash against corporate globalisation as foreshadowed by the post-war era of embedded liberalism (Ruggie 2004).

Echoing the critique of the mainstream and liberal treatments of GlobCon, critical political economy theorists have challenged the implicit pluralist and functionalist assumptions of GP3 architects and advocates. Both civil society groups in the anti-corporate globalisation movement (i.e. the Global Policy Forum) and critical theorists argue that partnership optimism disregards the issues and complexities of power while indirectly reifying existing structures of global inequality (Paine 2000; Gregoratti 2012). GP3s are explained not as a function to fill governance gaps or facilitate CSR, but as a legitimising mechanism of global neoliberalism and the structural power of capital by normalising market-led processes and coopting the neoliberal backlash from civil society (ibid). GP3s, critical theorists hold, are constituted by and in the interests of particular social forces and risk a potential corporate takeover of the global agenda, commercialisation of the UN system and cooptation of any counterhegemonic protest to corporate misconduct (ibid; Utting 2002; Utting and Zammit 2009). Critical research is demonstrating their soft, and hence weak, design in terms of their inadequate or non-existent monitoring and enforcement mechanisms which ultimately encourage corporations to shirk their already diluted CSR responsibilities (Sethi and Schepers 2014). Companies such as PetroChina, Nike, Nestlé and Shell, all of which are Global Compact signatories, have been shown to be engaging in business practices that violate core UN values, including human and labour rights and global environmental standards (ibid; TRAC 2000). Hence, GP3s have been understood as amounting to an emerging constitutional process that 'bluewashes' nefarious business activities in UN legitimacy while sidelining any meaningful regulatory framework that could facilitate changes to unsustainable and unethical corporate behaviour (Paine 2000; Utting 2002).

Despite the increasing academic attention and debate around GP3s, very few in-depth, systematic studies have looked into the partnerships of particular 
UN agencies and even less have considered the impact these relations have on the global agencies themselves (see Bull's (2010) discussion of UNESCO GP3s and Gregoratti's (2010) analysis of UNDP GP3s as exceptions). We have little insights into their complex power dynamics (including their structural and ideological power relations) nor the potential effects these may be having on the UN and global governance regimes. Furthermore, we are unaware of their implications for the particular global public goods in which they are designed to provide - in this case, protection and assistance of refugee populations. Therefore, this article offers an in-depth case study of UN-business partnerships to elucidate their underlying political nature and determine what they mean for their particular encompassing regime and processes of GlobCon more generally.

\section{A critical political economy methodology to constitutionalism and partnerships}

Considering the central roles played by corporate actors and market processes in GP3s, the instrumental capacity and power of multinational corporations and their economic legitimacy they command within the global political economy - as posited by both sides of the GP3 debate (Reinicke 2000; Gregoratti 2012) - this inquiry takes a neo-Gramscian/New Constitutionalist approach to understanding GP3s as a GlobCon process. As this analysis will demonstrate, this particular approach provides exceptional explanatory power in the case of UNHCR GP3s - GlobCon processes that are largely constituted by structural and ideological factors. This analysis, therefore, problematises the basic assumptions of the mainstream liberal and traditional approaches to GlobCon and the GP3 discourse that neglect underlying structural and ideological power relations in market processes and legal orders (Rajkovic 2010; Kennedy 2013).

This methodological framework borrows extensively from the neoGramscian literature outlined above but seeks to correct for a prominent shortcoming in the approach. Neo-Gramscian theory has been problematised for overblowing structural determination and being overly doctrinaire in its treatment of ideological hegemony, ultimately undermining the importance of agency and potential sources of counter-hegemony (Levy and Newell 2005; Ayers 2013). A variety of research has been conducted on the UN and UNHCR to show that the institutions exercise considerable strategic agency and power in their own right, much of which is a product of their moral legitimacy and global authority in their respective regimes (Andonova 2010; Hammerstad 2014). Therefore, this analysis will avoid the structure all-the-way-down approach often advanced by neo-Gramscian 
theorists and will consider the co-constitutive relationship between structure and agency. Power, then, is not structurally automatic but is enacted by purposive, strategic agents, both materially and ideologically. The issue in this case then is to determine to what extent structure impacts agency and vice versa.

Employing this analytical framework requires methods of in-depth historical and critical discourse analysis. A critical neo-Gramscian approach focuses primarily on the structural and ideological dimensions of power and places them within their historical materialist context. Therefore, this analysis uses methods of critical discourse analysis to perform an in-depth deconstruction of the GP3 discourse and unveil underlying relations of power that discourses reflect (van Dijk 1993; Fairclough 2003). These methods include the deconstruction of particular communicative acts, such as public statements and publications, and placing them within their political economy context (ibid). A particular focus will be on how partnerships are legitimated through discourse and the question of who benefits in these relations according to their distribution of relative gains, risks and commitments. This analysis also includes a simultaneous historical analysis of discourse and of the political economy of the GP3 process. This entails embedding the history and discourse of GP3s within the wider history and ideology of the global political economy. ${ }^{2}$ Hence, this article provides an illustrative case study and argument of neo-Gramscian theory with the hopes of illuminating structural and ideological dynamics in GlobCon processes.

This inquiry uses the UN High Commissioner for Refugees (UNHCR) as an illustrative case study of UN GP3s. The UNHCR was chosen for reasons of generalisability, for substantial knowledge gaps regarding the global refugee regime and for particular normative concerns. First, the UNHCR provides a highly comparable case to other UN agencies as it avoids the extremities on either side of having a longer, more intense historical experience with the business sector, such as the World Health Organization, ${ }^{3}$ or having relatively too little engagement with corporate actors. As the proceeding analysis will show, UNHCR GP3s clearly reflect

2 Information and sources were collected from primary sites - including UN, UNHCR and corporate partner reports, websites, public statements and other related documents - and secondary sources from previous research in Refugee and Forced Migration Studies and Global Political Economy.

3 Commentators have noted GP3s as playing some of their largest roles in the global health sector (Bull and McNeill 2007). One of the most widely cited UN-based GP3 is the Global Alliance for Vaccination and Immunization (GAVI), a partnership between WHO, UNICEF, the World Bank and the Bill \& Melinda Gates Foundation (Bull 2010). 
patterns and trends occurring in other UN agencies and programmes. This generalisability is extended to the level of global regimes as the policy processes of the UNHCR and refugee regime closely resemble those of the regimes where a UN agency or multilateral institution plays a central, constituting role (see Loescher et al. 2008). Second, a focus on UNHCR GP3s is meant to fill a crucial knowledge gap regarding the refugee regime, both within and outside of Refugee Studies, that has yet to fully recognise and critically interrogate the considerable roles multinational corporations play in refugee protection and assistance. Outside of the proponents of UNHCR GP3s in Refugee Studies (i.e. Betts et al. 2016), few have acknowledged this phenomenon. Finally, the UNHCR was chosen out of a normative concern for the well-being and rights of refugee populations, particularly at a time where refugee numbers are increasing at a similar rate of corporate engagement in refugee response.

\section{UNHCR-business 'partnerships': Constitutionalising business as usual}

\section{Overview}

As this analysis will demonstrate, UNHCR-business partnerships do not function as mutually beneficial collaborations, nor do they exist on a pluralist level playing field as mainstream understandings assume. Rather, they constitute an asymmetrical set of power relations largely shaped by the overarching structures of the global political economy and the particular structural conditions of the global refugee regime. Conditions specific to the refugee regime - including the agency's dependence on voluntary contributions, a successive series of refugee crises, decreasing state commitment to refugee resettlement, mounting institutional responsibilities and subsequent financial crises - have all severely constrained the UNHCR and its strategic agency. Simultaneously, the 'partnerships' paradigm spreading throughout the UN system, combined with an emerging marketoriented epistemic community and the advocacy of corporate partners, have constituted the interests of the UNHCR by articulating, legitimising and normalising GP3s and market processes in the refugee regime.

UNHCR GP3s have developed as a set of informal and voluntary governance rules, norms and processes and have become a de facto way of doing things - an unwritten 'GP3 constitution'. This constitution entails the delegation of legitimate authority to the corporate sector and the consolidation of their soft, voluntary CSR responsibilities. In this political arrangement, corporate partners accrue asymmetrical benefits while the UNHCR assumes the majority of risks, challenges and the more substantial commitments. 
Analysis of the UNHCR GP3 discourse shows how GP3s are constituted in the interests of business by offering new markets, positive branding opportunities and soft CSR initiatives. The UNHCR, on the other hand, is faced with new challenges to its institutional autonomy, legitimacy and populations under its mandate. Most importantly, the constituting structure and norms of GP3s, particularly those aligned with the tenants of neoliberalism, are having constitutive effects on the agency itself in a manner that may be undermining the institution's traditional rights-based ideology in favour of a marketisation of refugee response. These constitutive effects of this particular case of constitutionalism reveals important insights for the study and understanding of GlobCon processes more generally.

\section{Taking stock: Challenges posed by GP3s in the refugee regime}

The re-constitution of the UNHCR as a market facilitator and the marketisation of refugee response poses serious risks to the autonomy and legitimacy of the institution, the rights and well-being of refugee communities and the realisation of any meaningful regulatory framework for global corporate conduct. As this analysis outlines, the UNHCR engages with corporate partners in shared epistemic forums geared toward corporate knowledge-sharing, consultancy and advocacy activities (see UNHCR 2007a; BHF 2017a). Such processes have been shown to impact decision-making and the direction of policies of both states and international organisations. Cox (2012: 24) demonstrates the power of capital in decision-making at the state level where the structural 'position of corporations along the global supply chain' affords them representation and influence in the negotiations and other processes of US foreign policy development that relate to their particular interests. ${ }^{4}$ Chatterjee and Finger (1994) and Newell (2005) extend this analysis of corporate impact on policymaking to the global level, articulating the process through which business exerted significant influence on global environmental governance through its inclusion in major policy discussions and negotiations. At both the state and global level, multinational corporations have been able to assert themselves as authorities in particular policy areas, realign these areas to be conducive to their own interests and subsequently alter the direction of policies (ibid; Cox 2012). Hence, the access to policy negotiations and the structural positioning enjoyed by corporate actors in

4 The Business Roundtable, for instance, engaged with American trade advisory committees and played a considerable role in the development of the North American Free Trade Agreement (NAFTA), supporting Mexican privatisation initiatives and the liberalisation of investment (Cox 2012). 
the global economy affords them considerable influence in decision-making processes, thereby dispersing the decision-making autonomy of the UNHCR and other global public institutions.

The legitimacy of the UNHCR is henceforth challenged by these concessions of decision-making authority. Serious concerns have been raised regarding the accountability and legitimacy of the UN and its mandate in its relations with business (Bull and McNeill 2007; Bull 2010). Many commentators worry of an 'institutional capture' by business that redefines the agenda according to business interests and undermines the moral authority of the UN system (ibid; Utting 2000; Richter 2003). In the case of the UNHCR, the agency's legitimacy is additionally challenged in a more direct manner by its partnerships with companies that directly contradict the agency's core mandate. Unocal, a former Californian-based oil company now subsumed under ConocoPhillips, had partnered with the UNHCR despite being tied to complicity in human and labour rights violations in Burma, themselves causing massive displacement and creating refugees (TRAC 2000; Utting 2000).

The marketisation of refugee response also poses serious risks to those under the UNHCR's mandate. Stephens (2002) provides a historical analysis of the relationship between multinational corporations and human rights, outlining how the core driving force of markets and market actors, the profit motive, has contradicted with or directly violated human rights. Rather than aligning with human rights, corporate investment is ultimately amoral and subject to the calculations of what is economically viable, largely as a result of the fiduciary duty that corporate managers have to their shareholders (ibid). Samasource, for example, is a Silicon Valley based 'virtual micro work' company that partnered with the UNHCR to outsource small digital projects and was found to be exploiting the cheap labour it found in a Somali refugee camp in Kenya, paying its refugee employees approximately half of what an average refugee community member makes in the same camp conditions (Betts et al. 2016). ${ }^{5}$ Furthermore, there have been many concerns voiced over public services geared toward economic viabilities and profitability potentially diminishing the quality of services and the well-being of those receiving them (Wilks 2013: 133). In the case of the partnership between the UNHCR and the company IKEA - one of the most highly lauded refugee-based partnerships due to the company's design of store-like flat-packed refugee shelters (UNHCR 2017a) - a Swiss municipal government was unable to deploy its order of 62 'Better Refugee Shelters' due to their failure to meet national safety standards and proving to be 'highly combustible' (The Guardian 2015).

\footnotetext{
5 Some of Samasource's refugee employees walked off the job in protest and its partnership employment project ceased (ibid).
} 
Finally, the constitutionalisation of UN and UNHCR GP3s provides a challenging barrier to, or a redirection of, the development of a meaningful regulatory framework to holding corporations accountable at the global level and curbing unsustainable and unethical business practices outside of the soft, voluntary realm of CSR. UN GP3s offer the business community a chance to sidestep or coopt regulatory initiatives and provide opportunities to 'bluewash' unethical and unsustainable corporate behaviour in the legitimacy of the UN flag (Richter 2003; Utting and Zammit 2009). UN partnerships have been shown to advance little in the initiative of establishing corporate accountability or any oversight mechanisms on corporate conduct while at the same time advertising companies as socially responsible contributors to the global public good (ibid). Particular UNHCR partners, such as Nestlé and Nike, have been subject to some of the largest global consumer boycott campaigns for numerous rights and regulatory code violations yet continue to enjoy the appearance of social responsibility and legitimacy that comes with UNHCR affiliation (CorpWatch 1999; TRAC 2000).

The following case study identifies these challenges in the analysis of the embeddedness of UNHCR GP3s in the global political economy, their subsequent asymmetrical political relations they envelop and the manner in which they are re-constituting the agency along neoliberal lines.

\section{A historical and critical discourse analysis of UNHCR GP3s}

The UNHCR was established in 1950 as a temporary agency to assist the over 30 million Western Europeans displaced by World War II. The agency was mandated by the UN General Assembly to protect and assist European refugee populations, including provision of durable solutions to their forced displacement - either repatriation, local integration or third country resettlement. Following the decolonisation period of the 1960s and the subsequent civil and regional conflicts that erupted, the General Assembly passed the 1967 Protocol Relating to the Status of Refugees, waiving the temporal and geographic limitations of the original 1951 Convention. Today, the UNHCR's mandate has since expanded to encompass the protection and assistance of internally displaced persons and humanitarian and development activities for those in protracted encampment situations around the world (Loescher et al. 2008; UNHCR 2013).

Business engagement with the UNHCR is not an entirely new phenomenon. Being dependent on voluntary contributions, the agency has increasingly accepted financial contributions from the corporate sector since its inception. In contrast with the UN more generally, the agency's mandate has never been directly concerned with establishing oversight and global regulations for corporate conduct, putting the agency on a different trajectory of 
business relations relative to some other UN agencies. The UNDP, for instance, had a much more contentious relationship with the private sector in the earlier periods of UN-business engagements. The agency's 1999 Human Development Report proposed building 'the frameworks of a new global society and economy that respect differences, protect the weak and regulate the strong [...] Markets need institutions and rules', much to the consternation of the global business community (UNDP 1999). Though the UNHCR's earlier history with business was relatively less contentious, as the former UNHCR High Commissioner Sadako Ogata and the statements by business representatives indicate, there was still an air of hesitation and scepticism of conflicting motives during the early post-war and Cold War period (see Ogata 1999; BHF 2017a). In an address to business representatives in 1999, High Commissioner Ogata proposed 'sustainable profit' as the common goal between companies and the agency but with caution, stating:

[...] my concern - which I share with many others, in particular NGOs over the fact that some business groups unwittingly or not may be contributing both to war and to human rights violations. It is very well known, for example, that some of the worst refugee-producing conflicts in Africa today are partly fueled by business groups with interests in natural resources. In other countries, there are companies doing business with governments that violate human rights of their own people sometimes these companies even contribute to these violations, by further exploiting as cheap labor, persecuted and repressed groups [...] A spinoff effect of these practices is that it creates an atmosphere of suspicion around business-humanitarian relations (Ogata 1999).

In the period immediately preceding this speech, UNHCR-business relations centred primarily around philanthropic and procurement activities.

The UNHCR's partnership discourse emerged following the UN's introduction to the idea of the Global Compact. The agency faced additional institutional pressures to open itself up to further corporate engagement from certain conditions specific to the global refugee regime. During the Cold War, refugees possessed considerable geopolitical significance and were often exploited as symbols of either Western or Eastern moral bankruptcy (Gibney 2004). Following the consolidation of American hegemony in the post-Cold War period, this geopolitical value of refugees became obsolete and many Western states began to employ more pronounced restrictive refugee policies (ibid; Chimni 1998). Compounding the stress this placed on the UNHCR were a number of political and economic crises occurring throughout this period in the Global South, sparking new and increasingly complex situations of displacement 
(Gibney 2001). Subsequently, an unprecedented number of refugees were ending up in desolate camp settings with fewer alternatives for their resettlement. Though the UNHCR has demonstrated its command of considerable discursive power, emanating from its moral authority and strategic agency in the global refugee and migration regimes (Hammerstad 2014), this had not been sufficient under the regime's conditions to keep pace with the institution's expanding mandate and decreasing capacity.

This analysis conceptualises GP3s as relatively institutionalised, longterm and multidimensional engagements with for-profit actors at all stages of the policy process, including decision-making and policy formation. In this sense, UNHCR-business partnerships first materialised with the 1999 establishment of the Business Humanitarian Forum (BHF). The BHF is a self-described private research, consultancy and advocacy partnership, co-chaired by now former UNHCR Commissioner Sadako Ogata, the former Secretary-General of the ICC and the former President of Unocal Corporation (among other business representatives) (BHF 2017b). It is constituted on the premise of common goals between the public and private spheres and functions to 'bridge the gap of understanding and promote cooperation' (BHF 2017a). Responsibilities of the corporate sector within the BHF are based solely on voluntary CSR initiatives (BHF 2017a) with no codified legal constraints or oversight mechanisms put in place to govern internal or external corporate behaviour nor were any safeguards instituted to protect the institutional autonomy of the UNHCR. The BHF acted essentially as the first major link and epistemic forum - a shared space whereby ideas of governance are constructed, diffused and directed towards overarching agenda-setting and decision-making processes between the agency and business. Other UN agencies, including the UNDP, had established similar sites of corporate input. The UNDP created a joint Global Sustainable Development Facility (GSDF) with corporate partners that acted as the first 'joint management and decision-making mechanism' between the agency and business (Gregoratti 2010: 197).

Though the UNHCR had a relatively less contentious relationship with business in the earlier years than the UN system more generally, the agency's discourse was comparatively tentative and less optimistic than that professed by UN Secretary-General Annan in his introduction to the Global Compact. In her landmark speech made to the BHF on facilitating GP3s summarised above, High Commissioner Ogata stressed the inherent conflicts of interest between the agency and business. Echoing the Global Compact, Ogata rationalised the GP3 approach as a way to develop common interests. Working together, she reasoned, could help to bridge the public-private spheres and facilitate corporate accountability externally (Ogata 1999). Despite the professed discourse of CSR, no hard mechanisms 
or oversight procedures were raised to ensure corporate partners would assume further commitments nor have there been any subsequent indications or reports that the BHF has facilitated any change in the considerations of its corporate membership. Rather, the BHF has merely expedited corporate investment in specified humanitarian projects and facilitated corporate advocacy and knowledge input in humanitarianism response. The initial constitutionalisation process of UNHCR GP3s, therefore, placed no formal responsibilities, oversights or constraints on the corporate sector while redistributing agenda-setting and decision-making authority and concentrating risk with the UNHCR in terms of its institutional autonomy and legitimacy.

Ogata's rationalisation of UNHCR GP3s overshadowed the civil society opposition to the BHF. Corporate accountability advocates, such as CorpWatch and the Global Policy Forum, highlighted the unethical business practices of particular BHF partners, including Unocal's widely publicised rights violations in Burma and Nestlé's widely known infractions against infant formula codes and environmental standards (CorpWatch 1999; TRAC 2000). Critics of the BHF voiced their concerns over the asymmetrical benefits gained by business partners from BHF membership, including corporate interests in a voluntary regulatory environment, an opportunity to conceal nefarious business activities and increased influence in humanitarian governance (ibid). The UNDP's GSDF with corporate partners was subject to similar criticisms from civil society to the point where the partnership initiative was abandoned (Gregoratti 2010: 197). In the case of the UNHCR, however, non-governmental and other civil society organisations were not included or even acknowledged in the development and operations of the BHF, thereby relegating any form of third-party accountability measures or counterforces to the margins of the global refugee regime.

Throughout the early years of GP3 consolidation, conditions under which the UNHCR operated had increasingly placed significant operational constraints and financial pressures on the agency. New conflicts and situations of displacement produced new opportunities for the corporate sector to engage in refugee assistance. Microsoft, for example, established a long-term partnership with the UNHCR, initially contributing a newly designed refugee registration system for Kosovar refugees (at a time when it was facing significant stock devaluation as a result of multiple anti-trust lawsuits) (Suder and Nicolas 2009). The post-9/11 security concerns ushered in a new era of restrictive refugee policies across many Western, and increasingly Southern, states. Voluntary state contributions to the UNHCR were also becoming more politicised as states began to progressively earmark their contributions to specific strategic areas according to their respective interests (Barnett 2002; Loescher et al. 2008). The prolonged wars 
in Afghanistan and Iraq were also compounding the situation, creating a massive wave of new populations under the UNHCR's mandate.

Parallel with the global development (Gregoratti 2010), environmental (Andonova 2010) and other UN-based regimes (Bull and McNeill 2007), the GP3 approach had become normalised in the global refugee regime by the early 2000s. The UNHCR began to undergo a number of changes, both operationally and discursively, during this process. The agency established a number of offices as new institutional points of contact with business including the initial Private Sector and Public Affairs Service office and, later, the Corporate Foundation Partnership Unit (UN-NGLS 2017). The UNHCR also began playing a significant legitimising and normalising role for the GP3 process, making 'partnerships' a prominent part of its overall discourse and including specialised sections dedicated to GP3s and particular partners in its annual Global Report and Global Appeals publications since 2005. Throughout these reports the agency emphasises the common goals it shares with the private sector, including the 'development of more stable societies [which is] clearly good for business' (UNHCR 2005; 2007a). The UNHCR's discourse also began to emphasise the importance of applying 'the rigors of the marketplace' to refugee support and highlighting not only the funding contributions of the business sector, but also its specialised knowledge and expertise (UN Business 2017; UNHCR 2005; 2007a). This increasingly market-based discourse in the UNHCR's partnership agenda constituted a new governance norm in the regime - leveraging business ideas and servicing business interests while disregarding any de facto or de jure mechanisms to ensure institutional autonomy and corporate accountability.

In 2005 the UNHCR and corporate partners established a more comprehensive epistemic forum, the Council of Business Leaders. The Council is the self-described 'driver' of the UNHCR's GP3 program and is composed of representatives from five major corporations - Microsoft, Nestlé, Nike, Merck and PricewaterhouseCoopers - and chaired by the Deputy High Commissioner (UNHCR 2007a; 2007b). It has been purportedly established to facilitate corporate sector consultation on 'how to be more business-like in carrying out humanitarian work' and to create a more integrated partnership program (UNHCR 2007a). Constituted like the BHF and other CSR-based initiatives - including the UN's Global Compact - the Council does not entail any hard legal commitments on the part of corporate partners. Instead, it recognises voluntary contributions and the advocacy of business-friendly, market-based innovations to refugee assistance as themselves a form of CSR. As the BHF states: 
The BHF has used the synergy of public-private cooperation to build sustainable economic enterprises in post-conflict and developing areas. In this regard, the BHF built upon the business sector's corporate social responsibility (CSR) programs to motivate and energize these projects (BHF 2007a).

Civil society critics have protested against the inclusion of particular BHF partners in refugee assistance, including widely scrutinised companies such as Nike and Nestlé (CorpWatch 1999; TRAC 2000).

As outlined in the preceding section, these epistemic forums challenge the UNHCR's decision-making autonomy and subsequent legitimacy. This challenge is pronounced by the lack of other parties or institutional safeguards in the forums that could act as a counterforce to corporate infiltration of policy. As Newell (2005) and Cox (2012) have shown, such processes afford the business community an opportunity to infiltrate the UNHCR's decision-making processes with their considerable material capacity, structural position and economic legitimacy.

This intensification of corporate engagement in refugee assistance has continued apace in the post-2010 era. In 2011 the UNHCR underwent a 'modernisation' remit following a privately commissioned review of the organisation, undertaken by Synthesis Corp, that recommended opening up further to GP3s and leveraging corporate partners as sources of expertise and institutional innovation (Betts et al. 2016). Resulting out of this process was the creation of UNHCR Innovation, a collaborative research group and epistemic forum that leverages private entrepreneurialism in humanitarian ventures. Corporate Innovation partners include Vodafone Foundation, UPS, Hunt Power and Hewlett Packard and the partnership's council, known as the 'iCircle', further includes IKEA Foundation, Hunt Oil and Microsoft. The iCircle facilitates regular consultations and research initiatives amongst the UNHCR, business and researchers toward 'strategic guidance, technical expertise [and] advice on public-private partnerships' (Refugee Studies Centre 2014). Similar to the GP3 structure and governance norms that constitute the BHF and the Council of Business Leaders, UNHCR Innovation functions as a conduit for private and corporate input of ideas while neglecting any additional commitments on business partners toward CSR or behavioural change.

An epistemic community has developed out of the modernisation process and centred around this newly constituted governance arrangement, taking the intellectual leadership in advocating market mechanisms and corporate partnerships in the global refugee regime. Academics in this community promote corporate partnerships not only as sources of market knowledge and expertise for the UNHCR, but also as profit and branding opportunities 
for business. Refugee populations are now being branded as 'new humanitarian markets' with the potential for developing economies of scale amongst the lowest, yet largest, rung in the socioeconomic pyramid (see Betts et al. 2012; Betts et al. 2016). According to GP3 proponents, 'situations of displacement can provide opportunities to innovate, test new products and enter new markets, leading to increasing value for the company and its shareholders, including the opportunity to increase competitive advantage' (Boyer and DuPont 2016: 367). This discourse reflects a marked neoliberal reconstitution of refugee humanitarian relief that engages market forces and corporate interests as central to the process (Weiss 2013). Members of the community overlap across academia, the private sector and the epistemic forums, granting corporate partners and market advocates increased access to decision-making processes.

Enveloped within the epistemic community, the UNHCR's discourse has started to reflect this kind of marketised humanitarianism. The agency has begun to advertise refugee communities to potential corporate partners, appealing to their profit-driven interests in developing new markets and positive branding images (see UNHCR 2015; 2017c). As stated on the agency's website:

Collaboration with UNHCR provides businesses with branding, marketing and growth opportunities. Joint initiatives can also instill pride and loyalty among employees, as well as trust and credibility in customers and decision-makers. Benefits include positioning the company as a social actor, building an international profile, understanding new and emerging markets, identifying local and international partners and, in some cases, co-developing new products and solutions (UNHCR 2017c).

Starkly contrasting with the initial hesitation of business engagement in the UNHCR's earlier discourse, the agency explicitly encourages the workings of the market and disregards any further responsibilities for business partners. The UNHCR's partnership agenda highlights corporate engagement in refugee response in a manner resembling just another capitalist venture - as business-as-usual. There is no indication in the current discourse or in the UNHCR's partnership advertisements that GP3s are meant to facilitate any responsibilities other than those that work in the interests of business. Congruent with the dominant ideology of the global political economy (Soederberg 2012) and also that of the global refugee regime's market-based epistemic community, the ideology underlying the UNHCR's new discursive terrain is consistent with the tenants of neoliberalism which heralds market mechanisms as the primary driver of development and laissez-faire, voluntary regulatory schemes to allow for optimal market performance (Gill and Cutler 2014). 
The neoliberalisation of the UNHCR aligns with the experience of the UNDP. Gregoratti's (2010: 190) critical historical analysis of the agency's GP3s demonstrates how, despite the resistance mounted by civil society and the previously contentious relationship with the business community, the 'UNDP has positioned itself as a proponent of market-driven development'. The UNDP and business have engaged in numerous initiatives since the late 1990s and the agency 'embarked on a systematic program of collaboration with the private sector' with the creation of its Private Sector Division in 2007 (ibid: 192). Gregoratti shows that, over the last two decades, the UNDP has come to align its agenda with the ideology of corporate partners and the World Bank while increasingly evoking a business-friendly discourse.

The neoliberal manner in which UNHCR partnerships have been constituted asymmetrically privileges corporate partners in terms of the relative benefits they receive and the lack of risks and commitments they assume in these arrangements. According to the UNHCR and propartnership community, businesses voluntarily commit to financial and idea-based contributions and in return receive institutional commitments to a soft regulatory environment based on voluntary CSR, positive branding opportunities, subsequent global legitimacy and new massive markets in refugee service provisions for the potential development of refugee-based economies of scale (Boyer and DuPont 2016; UNHCR $2015 ; 2017 \mathrm{c})$. Additionally, corporate engagement in refugee response offers the unique opportunity for businesses to engage in epistemic and advocacy activities in forums that promote market- and business-friendly policies.

In absolute terms, the UNHCR benefits from the financial, in-kind and strategic contributions from corporate partners. The IKEA Foundation, for example, contributed over \$31 million to the agency in 2016 and Microsoft has developed new technologies in refugee registration and response (UNHCR 2017a). In relative terms, however, the agency benefits rather narrowly. A stated legitimising function of UNHCR partnerships is to fill the resource gaps in the face of receding state commitments and institutional capacities alongside its increasing mandate. However, corporate financial contributions have not kept any pace with budgetary demands. The UNHCR is in fact facing an unprecedented and continuously growing budget deficit (UNHCR 2017b), despite the fact of intensifying corporate involvement in the refugee regime. In relative terms then, intensifying corporate commitments have been more epistemic and ideological than they have been financial in nature. Furthermore, the voluntary nature of partnership initiatives greatly reduces the possibility of incurred risks for business partners. Potential voluntary investment risks undertaken by corporations under the guise of UNHCR partnerships are indistinguishable from any 
other venture investment undertaking with the former guided by the same logic and strategic risk calculations as the latter (if we are to assume, as Stephens (2002) and Wilks (2013) have shown, that corporations act according to their fiduciary duty to their shareholders). Hence, GP3 constitutions do not mandate business commitments beyond business interests. UNHCR partnerships, therefore, lack a mutual distribution of risks and commitments between the agency and business while corporate partners enjoy significantly disproportionate relative gains and the business-as-usual environment constituted in the humanitarian response marketplace.

The UNHCR has assumed the vast majority of risk and has made unmatched commitments to the partnership agenda. As previously shown, the agency faces severe challenges to its legitimacy and moral authority from its associations with companies with widely criticised human rights records (i.e. Unocal, Nike, Nestlé) (TRAC 2000; Utting 2000). As High Commissioner Ogata cautioned at the advent of UNHCR GP3s, other partnerships risk undermining the agency's core mandate of assistance, which includes upholding the well-being of refugees, by infringing on their socioeconomic and labour rights through the exploitive, self-interested behaviour of corporate partners. This exploitative behaviour of refugee communities is evident in the UNHCR-Samasource partnership. Furthermore, no institutional safeguards have been instituted in this constitutionalism process to ensure the autonomy of the agency. This is particularly an issue in regard to the agency's epistemic forums it shares with business and the roles they play in agenda-setting and decision-making. Corporations have perpetually gained increasing access to decision-makers throughout the UNHCR's GP3 history where their structural positioning in the global economy affords them economic legitimacy and authority (Cox 2012). Civil society or other third-party oversight actors and processes geared toward protecting the integrity of the agency's mandate have been either relegated to the outside of the partnership arrangements or neglected all together. This risks a potential 'institutional capture' - a reorganisation of the institution's overall agenda to reflect the interests of business (Utting 2000; Zammit 2003).

In sharp contradistinction to the lack of commitments by corporate partners, GP3s have induced constitutive commitments by the UNHCR essentially reconstituting the institution. The agency has undergone compelling operational and ideological changes toward the partnership agenda that have reconfigured it as a business facilitator. The overall processes through which the agency operates under GP3s have altered to include market actors and processes in the policy-making and decision-making stages. The agency has established multiple institutional points of contact with 
companies and engages in a number of shared epistemic forums to leverage input from business. Many of the agency's highlights in its annual reports revolve around areas that have been conducive to corporate sector focus and innovation (see UNHCR 2015; UNHCR Innovation 2017). Bull (2010: 193) found a similar trend in his analysis of UNESCO GP3s - that, in its partnership with Microsoft, for example, the agency had placed significantly more emphasis on information and communication technologies in education than previously stipulated in the agency's program. This analysis has shown how the UNHCR has also undergone a marked ideological shift reflected in the change from a humanitarian discourse grounded in rightsbased logic and consisting of a hesitant tone toward corporate motives to a discourse informed by global neoliberalism that places markets and economised self-interest at the centre of the humanitarian and development agenda (Gill and Cutler 2014). These operational and ideological changes indicate an existential re-constitutionalisation of the agency consistent with the critical theory conception of new constitutionalism.

Gill $(1995 ; 2014)$ articulated the process of new constitutionalism to explain the de facto and de jure international legal mechanisms and processes that lock state institutions into the global economy. New constitutionalism involves a neoliberal constitutionalisation of public institutions, including a restructuring of their regulatory regimes and interventionist policies, to make them more conducive to private sector investment and influence. As New Constitutionalists argue, this is part of a larger process of neoliberal global hegemony to the benefit of dominant social forces, particularly multinational corporations and the controllers of global capital (ibid). New constitutional arrangements are reflective of and reify the structural power of capital, designed in such a way as to make market actors the primary benefactors (Gill 1995; 2002; Gill and Cutler 2014). Though Gill applied this concept to states, this analysis finds its applicability at the level of global institutions and regimes. This new constitutionalism of the UNHCR and the global refugee regime is evident in the partnership agenda via the agency's market-oriented rearticulation that constitutes a business-as-usual governance environment for business, thereby locking in the agency as a conduit for the refugee humanitarian market. Understanding this process as an existential re-constitution helps to understand why, after all the unequal distribution of benefits, risks and commitments and the vocal criticisms from civil society, the UNHCR continues along the GP3 and market-based path. According to the UNHCR's most recent Global Appeal publication, the logic of GP3s maintains the same trajectory: 
[...] we are stepping up our engagement with the corporate sector, philanthropists, sports and other foundations. The engagement of the private sector individuals and entities plays an important role in helping us innovate, fostering positive attitudes, and sometimes, influencing policy. They are often also important donors, and we are also now boosting our efforts to raise $\$ 1$ billion from the private sector annually by 2026 (UNHCR 2018: 11).

\section{Conclusion: Lessons from UNHCR-business partnerships for GlobCon}

This historical and discursive analysis of UNHCR-business partnerships has showcased the undeniable presence and roles of multinational corporations in the global refugee regime, outlined the neoliberal constitutionalism of GP3s for humanitarian refugee relief, articulated these processes' inherent power relations and demonstrated their constitutive effects on the agency while noting the challenges these pose to the agency's autonomy, legitimacy, mandated population and global efforts toward corporate accountability. Interrogating the political economy of these partnerships reveals the 'for what and for whom' of this particular constitutionalism process. At least in this case, instead of constituting mutually beneficial collaborations in the name of UN values, GP3s constitute refugees as new markets, CSR initiatives as new humanitarian capitalist ventures and facilitate the constitutionalisation of the structural power of capital in the refugee regime and humanitarianism more generally. This marketisation of humanitarianism mirrors the outcome of the UNDP's GP3 process and the subsequent marketisation of development (Gregoratti 2010).

These findings offer important insights for the further study of GlobCon. First, it highlights how GlobCon is not only a process cultivated at the junction between politics and law but also within the global economy. In this case, market actors and processes have been central to the neoliberal constitutionalism in the refugee regime. Gill $(1995 ; 2014)$ has already revealed similar findings at the state level and Brown (2012) has articulated the global political economy processes of international law and global constitutionalism more generally. This article similarly advances the utility of a global political economy of GlobCon approach. Second and relatedly, though this analysis has relied on a stretched conception of GlobCon that primarily considers informal constitutional dynamics, UNHCR GP3s demonstrate the centrality of informality in current and emerging constitutional forms. In this case, such soft constitutionalism is primarily a result of a third insight: the pervasiveness of power in constitutionalism processes. As this analysis demonstrates, power is endogenous and at the 
heart of global legal and constitutionalist orders. The structural and ideological power of capital played a central role in constitutionalising UNHCR GP3s and their subsequent asymmetrical distributions of power, benefits, risks and commitments. As critical theorists have repeatedly shown, constitutions and legal orders often reflect particular normative ideological orientations and privilege particular social forces over others, subsequently institutionalising relations of socioeconomic inequality and injustice (Cox 1981; 1987; Anghie 2008; Gill and Cutler 2014).

Finally, this analysis has articulated the constitutive potential of global constitutions and reveals the necessity to ask the 'constitutionalism for what and for whom' questions advanced by critical theorists (Gill 1995; Brown 2012). The constitutionalisation of UNHCR GP3s is best understood not as the establishment of legal or institutional constraints and guiding governance processes, but the facilitation of institutional and regime change on an existential level. Global constitutions do not just direct and delegate governance, they (re)constitute that which governs and that which is being governed. In this case, the GP3 constitution has reconstituted the UNHCR as a business ally and market facilitator and has reconstituted refugee communities as market opportunities. Furthermore, if we set aside the predominating assumptions of functionalism and pluralism and critically look into precisely what is being constituted, we can form a better understanding of the precise legal, political and economic processes of GlobCon and generate a more informed normative position on global partnerships and constitutionalism more generally. Future GlobCon research could consider this alternative ontological conceptualisation of global constitutions in other areas of global governance. Understanding this process in the global refugee regime, in particular, is pertinent now more than ever considering the current pressure faced by the UNHCR in the midst of a historically unprecedented refugee crisis, the isolationism of the Trump administration and the increasing salience of xenophobic and nationalist sentiments in the Western world.

\section{References}

Andonova, Liliana. 2010. "Public-Private Partnerships for the Earth: Politics and Patterns of Hybrid Authority in the Multilateral System." Global Environmental Politics $10(2): 25-53$.

Anghie, Antony. 2008. Imperialism, Sovereignty and the Making of International Law. Cambridge: Cambridge University Press.

Ayers, Allison (ed). 2013. Gramsci, Political Economy, and International Relations Theory: Modern Princes and Naked Emperors. New York, NY: Palgrave Macmillan.

Barnett, Laura. 2002. "Global Governance and the Evolution of the International Refugee Regime." International Journal of Refugee Law 14(2/3):238-62. 
Betts, Alexander, Louise Bloom and Naohiko Omata. 2012. "Humanitarian Innovation and Refugee Protection." Humanitarian Innovation Project Working Paper No. 85, Refugee Studies Centre, University of Oxford.

Betts, Alexander, Louise Bloom, Josiah Kaplan and Naohiko Omata. 2016. Refugee Economies: Forced Displacement and Development. Oxford: Oxford University Press.

Bexell, Magdalena and Ulrika Morth (eds). 2010. Democracy and Public-Private Partnerships in Global Governance. London: Palgrave Macmillan.

BHF (Business Humanitarian Forum). 2017a. 'History'. Available at: <http://www.bhforum. org/aboutus/History.aspx?tab=1\&nav=2332>.

BHF. 2017b. 'Organization'. Available at: <http://www.bhforum.org/aboutus/organization. aspx?tab=1\&nav=2333>.

Bogdandy, Armin von and Sergio Dellavalle. 2009. "Universalism Renewed: Habermas' Theory of International Order in Light of Competing Paradigms." German Law Journal 10(1):5-30.

Boyer, Glaucia and Yannick DuPont. 2016. "The Contribution of the Private Sector to Solutions of Displacement." Forced Migration Review 52:36-8.

Brown, Garrett. 2012. "The Constitutionalization of What?" Global Constitutionalism $1(2): 201-28$.

Buckel, Sonja and Andreas Fischer-Lescano. 2009. "Gramsci Reconsidered: Hegemony in Global Law." Leiden Journal of International Law 22(3):437-54.

Bull, Benedicte. 2010. "Rethinking Multilateralism: Global Governance and Public-Private Partnerships with the UN.” In Business and Global Governance, edited by Morten Ougaard and Anna Leander, 181-99. New York, NY: Routledge.

Bull, Benedicte and Desmond McNeill. 2007. Development Issues in Global Governance: Public-Private Partnerships and Market Multilateralism. New York, NY: Routledge.

Bull, Benedicte and Desmond McNeill. 2010. "From Business Unusual to Business as Usual: The Future Legitimacy of PPPs with Multilateral Organizations." In Democracy and Public-Private Partnerships in Global Governance, edited by Magdalena Bexell and Ulrika Morth, 103-21. London: Palgrave MacMillan.

Buzan, Barry. 1996. “A Timeless Wisdom of Realism?” In International Theory: Positivism and Beyond, edited by Steve Smith, Ken Booth and Marysia Zalenski, 47-65. Cambridge: Cambridge University Press.

Chatterjee, Pratap and Matthias Finger. 1994. The Earth Brokers: Power, Politics and World Development. New York, NY: Routledge.

Chimni, B.S. 1998. "The Geopolitics of Refugee Studies: A View from the South.” Journal of Refugee Studies 11(4):350-74.

CorpWatch. 1999. "Groups Expose More United Nations Affiliations with Corporate Predators." (23 September) at: <http://www.corpwatch.org/article.php?id=940>.

Cox, Robert. 1981. "Social Forces, States and World Orders: Beyond International Relations Theory." Millennium: Journal of International Studies 10(1):126-55.

Cox, Robert. 1987. Production, Power, and World Order: Social Forces in the Making of History. New York, NY: Columbia University Press.

Cox, Ronald. 2012. "Corporate Finance and US Foreign Policy." In Corporate Power and Globalization in US Foreign Policy, edited by Ronald Cox, 11-30. New York, NY: Routledge.

Cutler, Claire. 2010. "Unthinking GATS: A Radical Political Economy Critique of Private Transnational Governance.” In Business and Global Governance, edited by Morten Ougaard and Anna Leander, 78-96. New York, NY: Routledge.

Cutler, Claire. 2014. "New Constitutionalism and the Commodity Form of Global Capitalism." In New Constitutionalism and World Order, edited by Stephen Gill and Claire Cutler, 45-62. New York, NY: Cambridge University Press. 
Cutler, Claire, Virginia Haufler and Tony Porter (eds). 1999. Private Authority and International Affairs. Albany, NY: State University of New York Press.

Dunoff, Jeffrey, Antje Wiener, Mattias Kumm, Anthony Lang Jr. and James Tully. 2015. "Editorial: Hard Times: Progress Narratives, Historical Contingency and the Fate of Global Constitutionalism." Global Constitutionalism 4(1):1-17.

Fairclough, Norman. 2003. Analyzing Discourse: Textual Analysis for Social Research New York, NY: Routledge.

Farrands, Christopher and Owen Worth. 2005. "Critical Theory in Global Political Economy: Critique? Knowledge? Emancipation?” Capital \& Class 85:42-62.

Fritsch, Stefan. 2008. "The UN Global Compact and the Global Governance of Corporate Social Responsibility: Complex Multilateralism for a More Human Globalization?” Global Society 22(1):1-26.

Gibney, Matthew. 2001. "The State of Asylum: Democratization, Judicialization and Evolution of Refugee Policy.” New Issues in Refugee Research Working Paper No. 5. Geneva: UNHCR. Gibney, Matthew. 2004. The Ethics and Politics of Asylum: Liberal Democracy and the Response to Refugees. Cambridge: Cambridge University Press.

Gill, Stephen. 1995. "Globalization, Market Civilization, and Disciplinary Neoliberalism." Journal of International Studies 24(3):399-423.

Gill, Stephen. 1998. "New Constitutionalism, Democratization and Global Political Economy." Pacific Review: Peace, Security \& Global Change 10(1):23-38.

Gill, Stephen. 2002. "Constitutionalizing Inequality and the Clash of Globalizations." International Studies Review 4(2):47-65.

Gill, Stephen. 2014. "Market Civilization, New Constitutionalism and World Order." In New Constitutionalism and World Order, edited by Stephen Gill and Claire Cutler, 29-44. New York, NY: Cambridge University Press.

Gill, Stephen and Claire Cutler (eds). 2014. New Constitutionalism and World Order. New York, NY: Cambridge University Press.

Gregoratti, Catia. 2010. "UNDP, Business Partnerships, and the (UN)Democratic Governance of Development." In Democracy and Public-Private Partnerships, edited by Magdalena Bexell and Ulrika Morth, 190-210. London: Palgrave Macmillan.

Gregoratti, Catia. 2012. "Transnational Partnerships: Whose Democracy? Whose Justice?” Global Society 26(4):515-34.

The Guardian. 2015. "Swiss City Buys Ikea Shelters to House Refugees, Then Ditches Them over Fire Risk.” (19 December) at: <https://www.theguardian.com/world/2015/dec/19/ swiss-city-buys-ikea-shelters-to-house-refugees-then-ditches-them-over-fire-risk>.

Hall, Rodney and Thomas Biersteker (eds). 2002. The Emergence of Private Authority in Global Governance. Cambridge: Cambridge University Press.

Hammerstad, Anne. 2014. The Rise and Decline of a Global Security Actor: UNHCR, Refugee Protection and Security. Oxford: Oxford University Press.

Haufler, Virginia. 2000. Private Sector International Regimes. In Non-State Actors and Authority in the Global System, edited by Richard Higgot, Geoffrey Underhill and Andreas Bieler, 121-37. New York, NY: Routledge.

Higgot, Richard, Geoffrey Underhill and Andreas Bieler (eds). 2000. Non-Actors and Authority in the Global System. New York, NY: Routledge.

Kell, George and John Ruggie. 1999. "Global Markets and Social Legitimacy: The Case of the 'Global Compact'." Transnational Corporations 8(3):101-20.

Kennedy, Law. 2013. "Law and the Political Economy of the World." Leiden Journal of International Law 26:7-48.

Keohane, Robert and Joseph Nye. 1977. Power and Interdependence: World Politics in Transition. Boston, MA: Little, Brown. 
Kingsbury, Benedict, Nico Krish and Richard Stewart. 2005. "The Emergence of Global Administrative Law". Law and Contemporary Problems 68(3):15-61.

Krasner, Stephen. 1983. International Regimes. Ithaca, NY: Cornell University Press.

Kratochwil, Friedrich and John Ruggie. 1986. "International Organization: A State of the Art on an Art of the State." International Organization 40(4):753-75.

Kumm, Mattias, Anthony Lang Jr., James Tully and Antje Wiener. 2014. "Editorial: How Large Is the World of Global Constitutionalism?” Global Constitutionalism 3(1):1-8.

Lawrence, Jessica. 2013. "Contesting Constitutionalism: Constitutional Discourse at the WTO." Global Constitutionalism 2(1):69-90.

Levy, David and Daniel Egan. 2000. "Corporate Political Action in the Global Polity: National and Transnational Strategies in the Climate Change Negotiations." In Non-State Actors and Authority in the Global System, edited by Richard Higgot, Geoffrey Underhill and Andreas Bieler, 138-54. New York, NY: Routledge.

Levy, David and Peter Newell (eds). 2005. The Business of Global Environmental Governance. Cambridge, MA: MIT Press.

Lipson, Charles. 1991. "Why Are Some International Agreements Informal?” International Organization 45(4):495-538.

Loescher, Gil, Alexander Betts and James Milner. 2008. The United Nations High Commissioner for Refugees (UNHCR): The Politics and Practice of Refugee Protection in the TwentyFirst Century. New York, NY: Routledge.

McCorquodale, Robert. 2013. "Pluralism, Global Law and Human Rights: Strengthening Accountability for Human Rights Violations." Global Constitutionalism 2(2):287-315.

Morton, Adam. 2003. "Social Forces in the Struggle over Hegemony: Neo-Gramscian Perspectives in International Political Economy." Rethinking Marxism 15(2):153-79.

Newell, Peter. 2005. "Business and International Environmental Governance: The State of the Art." In The Business of Global Environmental Governance, edited by David Levy and Peter Newell, 21-45. Cambridge, MA: MIT Press.

Ogata, Sadako. 1999. "Can Business Help? Partnership and Responsibilities in Humanitarian Work.” Speech made to Business Humanitarian Forum (1 November) at: <http://www. bhforum.org/pdf/ogata_011199.pdf>.

Paine, Ellen. 2000. "The Road to the Global Compact: Corporate Power and the Battle over Global Public Policy at the United Nations." Global Policy Forum. Available at: <https:// www.globalpolicy.org/global-taxes/32188-the-road-to-the-global-compact.html>.

Peters, Anne. 2009. "The Merits of Global Constitutionalism." Indiana Journal of Global Legal Studies 16(2):297-411.

Rajkovic, Nikolas. 2010. “'Global Law' and Governmentality: Reconceptualizing the 'Rule of Law' as Rule 'Through' Law.” European Journal of International Relations 18(1):29-52.

Rasche, Andreas and Sandra Waddock. 2014. "Global Sustainability Governance and the UN Global Compact: A Rejoinder to Critics.” Journal of Business Ethics 122(2): 209-16.

Refugee Studies Centre. 2014. "Alexander Betts, RSC Director, Meets Refugees in Jordan with UNHCR Innovation Circle” (24 November) at: <https://www.rsc.ox.ac.uk/news/rscdirector-meets-refugees-in-jordan-with-unhcr-innovation-icircle>.

Reinicke, Wolfgang. 2000. Critical Choices: The United Nations, Networks, and the Future of Global Governance. Ottawa, ON: International Development Research Centre.

Reinicke, Wolfgang and Francis Deng. 2000. Critical Choices: The United Nations, Networks, and the Future of Global Governance. Ottawa, ON: IDRC.

Richter, Judith. 2003. “'We the Peoples' or 'We the Corporations'? Critical Reflections on UN-Business 'Partnerships'.” Geneva: Geneva Infant Feeding Association (GIFA) and International Baby Food Action Network (IBFAN). 
Ruggie, John. 2001. "global_governance.net: The Global Compact as Learning Network." Global Governance 7(4):371-8.

Ruggie, John. 2004. "Reconstituting the Global Public Domain - Issues, Actors, and Practices." European Journal of International Relations 10(4):499-531.

Schäferhoff, Marco, Sabine Campe and Christopher Kaan. 2009. "Transnational PublicPrivate Partnerships in International Relations: Making Sense of Concepts, Research Frameworks, and Results." International Studies Review 11(3):451-74.

Sell, Susan. 2000. "Structures, Agents and Institutions: Private Corporate Power and the Globalization of Intellectual Property Rights." In Non-State Actors and Authority in the Global System, edited by Richard Higgot, Geoffrey Underhill and Andreas Bieler, 91-106. New York, NY: Routledge.

Sethi, Prakash and Donald Schepers. 2014. "United Nations Global Compact: The PromisePerformance Gap.” Journal of Business Ethics 122(2):193-208.

Snidal, Duncan. 1985. “Coordination versus Prisoners' Dilemma: Implications for International Cooperation and Regimes." The American Political Science Review 79(4):923-42.

Soederberg, Susanne. 2007. "Taming Corporations or Buttressing Market-Led Development? A Critical Assessment of the Global Compact." Globalizations 4(4):500-13.

Soederberg, Susanne. 2012. "Power, Neoliberalism, and the G20 Summits." In Corporate Power and Globalization in US Foreign Policy, edited by Ronald Cox, 162-84. New York, NY: Routledge.

Stein, Arthur. 1982. "Coordination and Collaboration: Regimes in an Anarchic World." International Organization 36(1):299-324.

Stephens, Beth. 2002. "The Amorality of Profit: Transnational Corporations and Human Rights." Berkeley Journal of International Law 20(1):45-90.

Suder, Gabriele and Nina Nicolas. 2009. "Microsoft's Partnership with UNHCR - Pro Bono Publico?" Journal of Business Ethics Education 6:1-16.

Tesner, Sandrine and George Kell. 2000. United Nations and Business: A Partnership Recovered. New York, NY: St. Martin's Press.

Teubner, Gunther and Gareth Norbury. 2012. Constitutional Fragments: Societal Constitutionalism and Globalization. Oxford: Oxford University Press.

Therien, Jean-Philippe and Vincent Pouliot. 2006. "The Global Compact: Shifting the Politics of International Development." Global Governance 12(1):55-75.

TRAC (Transnational Resource and Action Center). 2000. "Tangled up in Blue: Corporate Partners at the United Nations." Available at: <http://s3.amazonaws.com/corpwatch. org/downloads/tangled.pdf>.

Tully, James, Jeffrey Dunoff, Anthony Lang Jr., Mattias Kumm and Antje Wiener. 2016. "Editorial: Introducing Global Integral Constitutionalism." Global Constitutionalism $5(1): 1-5$.

UN (United Nations). 1999. "Secretary-General Proposes Global Compact on Human Rights, Labour, Environment, in Address to World Economic Forum in Davos." (1 February) at: <http://www.un.org/press/en/1999/19990201.sgsm6881.html>.

UN Business. 2017. "UNHCR Profile." Available at: <https://business.un.org/en/entities/30>.

UNDP (United Nations Development Programme). 1999. Human Development Report. New York, NY: Oxford University Press.

UNHCR (United Nations High Commissioner for Refugees). 2005. "The Global Report 2004." Available at: <http://www.unhcr.org/4a0c13d76.html>.

UNHCR. 2007a. “The Global Report 2006.” Available at: <http://www.unhcr.org/501f7d2e2. html>.

UNHCR. 2007b. “Global Appeal 2008-2009.” Available at: <http://www.unhcr.org/publ/ PUBL/474ac8c12.pdf>. 
UNHCR. 2013. "Note on the Mandate of the High Commissioner for Refugees and His Office." Available at: <http://www.unhcr.org/protection/basic/526a22cb6/mandatehigh-commissioner-refugees-office.html>.

UNHCR. 2015. "Doing Business with UNHCR. Budapest: Procurement Management and Contracting Service (PMCS), Department of Energy, Security and Supply DESS.” Available at: <http://www.unhcr.org/admin/sts/3b9203194/business-unhcr-2015.html>.

UNHCR. 2017a. "Figures at a Glance." Available at: <http://www.unhcr.org/figures-at-aglance.html>.

UNHCR. 2017b. "Financials." Available at: <http://reporting.unhcr.org/financial>.

UNHCR. 2017c. "Private Sector Supporters.” Available at: <http://www.unhcr.org/privatesector-supporters.html>.

UNHCR. 2018. “Global Appeal 2018-2019.” Available at: <http://www.unhcr.org/ publications/fundraising/5a0c05027/unhcr-globalappeal2018-2019-full-report.html>.

UNHCR Innovation. 2017. "Partners.” Available at: <http://www.unhcr.org/innovation/ partners/>.

UN-NGLS (United Nations Non-Governmental Liaison Service). 2017. "UNHCR.” Available at: <https://unngls.org/index.php/engage-with-the-un/un-civil-society-contact-points/141united-nations-high-commissioner-for-refugees-unhcr>.

Utting, Peter. 2000. UN-Business Partnerships: Whose Agenda Counts? Geneva: United Nations Research Institute for Social Development.

Utting, Peter. 2002. "The Global Compact and Civil Society: Averting a Collision Course." Development in Practice 12(5):644-6.

Utting, Peter and Ann Zammit. 2009. "United Nations-Business Partnerships: Good Intentions and Contradictory Agendas." Journal of Business Ethics 90(1):39-56.

van Dijk, Teun A. 1993. "Principles of Critical Discourse Analysis." Discourse \& Society $4(2): 249-83$.

Wiener, Antje, Anthony Lang Jr., James Tully, Miguel Poiares Maduro and Mattias Kumm. 2012. "Editorial: Global Constitutionalism: Human Rights, Democracy and the Rule of Law." Global Constitutionalism 1(1):1-15.

Wilks, Stephen. 2013. The Political Power of the Business Corporation. Northhampton, MA: Edward Elgar.

Weiss, Thomas. 2000. "Governance, Good Governance and Global Governance: Conceptual and Actual Challenges." Third World Quarterly 21(5):795-814.

Weiss, Thomas. 2013. Humanitarian Business. Malden, MA: Polity Press.

Zammit, Ann. 2003. Development at Risk: Rethinking UN-Business Partnerships. Geneva: The South Centre and United Nations Research Institute for Social Development. 